See Article page 937

\section{Commentary: Implications of coronavirus disease 2019 (COVID-19) for cardiac surgery: Priorities and decisions}

\author{
Keshava Rajagopal, MD, PhD \\ वेदमनूच्याचार्यो अन्तेवासनिमनुशास्ता \\ सत्यं वद धर्मं चर \\ vedamanuиchyaachaaryo antevaasinamanushaasti \\ satyam vada; dharmam chara \\ "Having taught the Vedas, the teacher exhorts the \\ disciple: Speak the Truth. Perform the Duty." \\ —Taittiriya Upanishad 1.11 (c. 400-600 BC)
}

It is straightforward that one ought to speak the truth and perform one's duty. These ideals permeate almost all faiths and philosophies. But almost all of them leave 2 questions unanswered, because those questions have answers that vary according to individual circumstances. These are: what are one's duties (ie, how can they be identified), and how should numerous duties be prioritized? Crises offer such opportunities for reflection.

In this issue of the Journal, the cardiac surgical faculty of Columbia University-Presbyterian Medical Center offer their perspectives on prioritization of duties in the context of the coronavirus disease 2019 (COVID-19) pandemic. ${ }^{1}$ Briefly summarized, emergent cardiac operations continued to be undertaken, urgent operations were stratified according what was in good faith deemed necessary to be undertaken for patients to safely live outside the medical center environment, and "elective" operations were deferred ("elective" is in quotation marks because one could reasonably argue that nothing in cardiac surgery is truly elective, even those operations that are performed prophylactically, in the absence of current symptomatic or physiologic derangements). Other centers have adopted such policies,

\footnotetext{
From the Department of Clinical Sciences, University of Houston College of Medicine, and Houston Heart, HCA Houston Healthcare, Houston, Tex.

Disclosures: The author reported no conflicts of interest.

The Journal policy requires editors and reviewers to disclose conflicts of interest and to decline handling or reviewing manuscripts for which they may have a conflict of interest. The editors and reviewers of this article have no conflicts of interest.

Received for publication May 18, 2020; accepted for publication May 18, 2020; available ahead of print June 4, 2020.

Address for reprints: Keshava Rajagopal, MD, PhD, Department of Clinical Sciences, University of Houston College of Medicine, Houston Heart, HCA Houston Healthcare, 1200 Binz St, Suite 900, Houston, TX 77004 (E-mail: krajago2@ central.uh.edu).

J Thorac Cardiovasc Surg 2020;160:951-2

$0022-5223 / \$ 36.00$

Copyright (C) 2020 by The American Association for Thoracic Surgery

https://doi.org/10.1016/j.jtcvs.2020.05.064
}

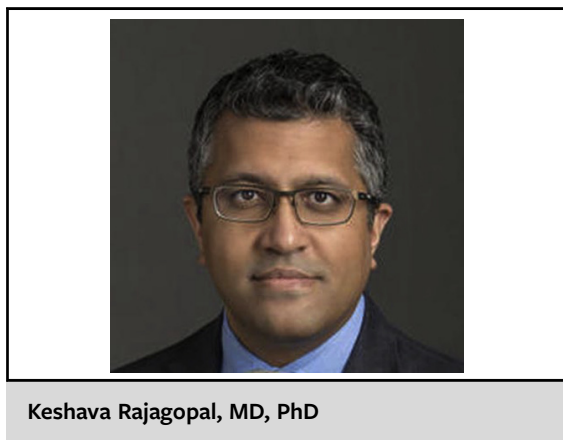

CENTRAL MESSAGE

The COVID-19 pandemic has

caused cardiac surgeons to

reassess their duties and

priorities.

but the rationales provided in this report are particularly thoughtful and instructive. Specifically, although we have a good sense of what is emergent, differentiating truly urgent from semi-urgent from elective is difficult. Reasoning, data regarding the timely operative versus delayed operative versus nonoperative histories of disease, and individual surgeon experience all ought to inform the development of criteria.

The experience reported embodies honesty and duty. However, some questions remain. Why have we drastically decreased operative volumes during the COVID-19 pandemic if the majority of our work is "life-saving?" The fact that operative volumes have been intentionally decreased suggests that we have concluded that inhospital care of patients afflicted with COVID-19 is more life-saving and important than the vast majority of cardiac surgical procedures. It is possible that our work, in the context of the resources required, in fact does not save many lives, particularly relative to less resource-intensive nonoperative treatments. It is worth noting that the greatest contributors to improved human life expectancy relate to simple public health initiatives: public sanitation (separating potable water from waste), modern obstetric and perinatal care (particularly aseptic technique), immunization, and antimicrobial drugs. Cardiac surgery is a comparatively small contributor to these improvements. Yet, unlike many other fields within medicine, in cardiac surgery, our work disproportionately saves lives, and does so acutely. We then need to ask at least 2 questions as a general matter, not simply in the context of an active pandemic. First, within an academic cardiac surgical service, should lifesaving operations always be prioritized (if this were so, 
perhaps transplants would be performed more commonly during the day, and many general adult cardiac operations would be performed at night), and not just prioritized, but actively sought out from referring centers (which would increase urgent and emergent operative volumes further, and decrease or at least delay less urgent or elective cases)? Second, the aforementioned question should be posed across service lines-between cardiac surgery and general thoracic surgery, or vascular surgery, or general surgery; if so, concepts such as operating rooms dedicated to specific services or surgeons, or "block time," become obsolete.

On the other hand, coming back to the COVID-19 pandemic, is it possible that decision-making is faulty? Should elderly patients or those with multiple comorbid conditions, both of whom have diminished hospital and long-term survival in comparison with younger and healthier patients, undergo intensive care unit admission, invasive mechanical ventilation, or more advanced care? If the answer to that question is no in general, then the negative impact of the pandemic upon cardiac surgery and other disciplines would be far less. And thus, although honesty and duty are necessary conditions, they are not sufficient. We have to humbly ask and answer the difficult questions of what our duties ought to be, and how to prioritize them.

\section{Reference}

1. George I, Salna M, Kobsa S, Deroo S, Kriegel J, Blitzer D, et al. The rapid transformation of cardiac surgery practice in the COVID-19 pandemic: insights and clinical strategies from a center at the epicenter. J Thorac Cardiovasc Surg. 2020;160:937-47.e2.
See Article page 937.

\section{Commentary: Pandemic deployment and surgical soldiership}

\section{Daniel J. Goldstein, MD}

With the onslaught of the Coronavirus Disease 2019 (COVID-19) pandemic, institutions, particularly those in the eye of the New York storm, had to rapidly and thoroughly devise and implement strategic plans to face the unprecedented myriad challenges posed by this wretched pathogen. In this article ${ }^{1}$ by the members of the Department of Surgery at Columbia Presbyterian Medical Center in northern Manhattan, the authors describe in luxurious detail their comprehensive, cogent, and commonsensical approach to optimizing care of patients, use of manpower, and maximizing use of vital space and equipment.

\footnotetext{
From the Department of Cardiothoracic and Vascular Surgery, Montefiore Medical Center, Albert Einstein College of Medicine, Bronx, NY.

Disclosures: The author reported no conflicts of interest.

The Journal policy requires editors and reviewers to disclose conflicts of interest and to decline handling or reviewing manuscripts for which they may have a conflict of interest. The editors and reviewers of this article have no conflicts of interest.

Received for publication May 14, 2020; accepted for publication May 14, 2020; available ahead of print June 5, 2020.

Address for reprints: Daniel J. Goldstein, MD, 3400 Bainbridge Ave, MAP Building, 5th Floor, Bronx, NY 10467 (E-mail: dgoldste@montefiore.org).

J Thorac Cardiovasc Surg 2020;160:952-3

$0022-5223 / \$ 36.00$

Copyright (c) 2020 by The American Association for Thoracic Surgery

https://doi.org/10.1016/j.jtcvs.2020.05.059
}

Check for updates

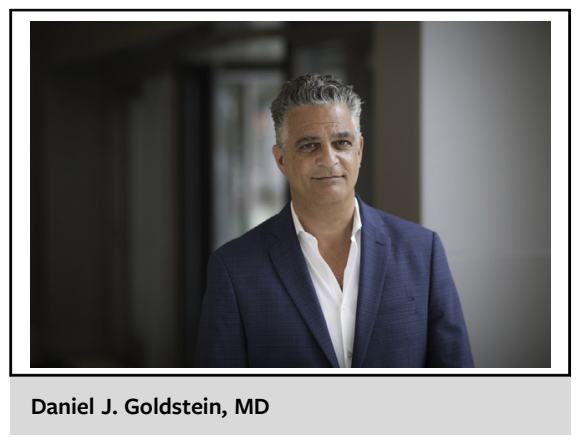

CENTRAL MESSAGE

A necessary quality for aspiring and practicing surgeons is preparedness. Precious lessons in

how to manage resources, deploy personnel, and prioritize cardiac surgery patients in the midst of a pandemic are presented.

The first half of the article discusses the tactics used that include transitioning to telemedicine platforms for outpatient visits, halting elective surgery (the main revenuegenerating activity in any hospital), and redeploying staff at all levels to serve the explosive need for COVID-19 intensive care unit (ICU) staffing. None of these actions are 